Article

\title{
Ethanol, Corn, and Soybean Price Relations in a Volatile Vehicle-Fuels Market
}

\author{
Zibin Zhang ${ }^{1}$, Luanne Lohr ${ }^{2}$, Cesar Escalante ${ }^{2}$ and Michael Wetzstein ${ }^{2, *}$ \\ 1 Economics, Zhejiang University, Hangzhou 310027, China; E-Mail: ZbZhang@uga.edu \\ 2 Agricultural and Applied Economics, University of Georgia, Athens, GA 30602, USA; E-Mails: \\ Llohr@uga.edu; Cescalan@uga.edu
}
* Author to whom correspondence should be addressed; E-Mail: MWetz@uga.edu; Tel.: +1 (706) 542- 0758; Fax: +1 (706) 542-0739.

Received: 22 April 2009; in revised form: 22 May 2009 / Accepted: 25 May 2009 /

Published: 2 June 2009

\begin{abstract}
The rapid upward shift in ethanol demand has raised concerns about ethanol's impact on the price level and volatility of agricultural commodities. The popular press attributes much of this volatility in commodity prices to a price bubble in ethanol fuel and recent deflation. Market economics predicts not only a softening of demand to high commodity prices but also a positive supply response. This volatility in ethanol and commodity prices are investigated using cointegration, vector error corrections (VECM), and multivariate generalized autoregressive conditional heteroskedascity (MGARCH) models. In terms of derived demand theory, results support ethanol and oil demands as derived demands from vehicle-fuel production. Gasoline prices directly influence the prices of ethanol and oil. However, of greater significance for the fuel versus food security issue, results support the effect of agricultural commodity prices as market signals which restore commodity markets to their equilibriums after a demand or supply event (shock). Such shocks may in the short-run increase agricultural commodity prices, but decentralized freely operating markets will mitigate the persistence of these shocks. Results indicate in recent years there are no long-run relations among fuel (ethanol, oil and gasoline) prices and agricultural commodity (corn and soybean) prices.
\end{abstract}

Keywords: agricultural commodities; biofuel; ethanol; food versus fuel 


\section{Introduction}

The rapid upward shift in ethanol demand has raised concerns about ethanol's impact on the price level and volatility of agricultural commodities. Recently, the prices of corn and soybeans, the nation's top two crops in total production, doubled and then sharply declined. The popular press attributes much of this run up in commodity prices to the swelling demand for ethanol fuel and the decline to a falloff in this demand [1]. Market economics predicts not only a softening of demand to high commodity prices but also a positive supply response [2-4]. In the fall of 2008, this prediction was confirmed with declines in domestic and foreign demand and higher expected crop harvests. A sharp hike in 2006 corn prices precipitated corn acreage reaching historic highs with a corresponding drop in soybean acreage yielding higher soybean prices [5]. The recent boom in ethanol refining capacity has resulted in an ethanol economic bubble which dampened the ethanol price. This price decline in conjunction with recent declines in vehicle fuels and lack of credit availability has forced some ethanol refineries to shutdown and retarded expected entry of others [1]. Although increased use of ethanol is mandated by the federal Renewable Fuel Standard, the industry is currently experiencing over capacity. The 2009 Renewable Fuel Standard will be $10.22 \%$ to ensure that at least 11.1 billion gallons renewable fuels are blended into gasoline. Most of these renewable fuels will be supplied by ethanol refining, which will help the industry to recover. These current fluid ethanol, corn, and soybean markets manifest in both the first and second moments of ethanol, corn, and soybean price distributions. Not only does ethanol potentially influence the level of corn and soybean prices, but it can also impact their price volatility.

Understanding and predicting price leadership between ethanol and the corn and soybean agricultural commodities leads to better policy. Persistent changes in volatility can increase the risk exposure of agricultural producers and ethanol refiners and alter hedging decisions and incentives to invest. However, such an understanding of the linkages between ethanol and agricultural commodity prices is pertinent beyond these producer decisions. By understanding the pricing relations, light is shed on the current food versus fuel debate centering on the dynamics of ethanol, corn, and soybean prices [6]. This food versus fuel trade-off emerged on a global scale with the 2007-2008 world agricultural commodity prices crisis. Biofuels in general will compete for renewable and nonrenewable resources and thus impact its sustainability and that of food. Increased cultivation of crops for biofuels will causes land-use shifts that have impacts on global natural resources and environmental sustainability.

Given the volatility in ethanol, corn, and soybean markets, the following questions are addressed. First, are there any long-run relationships between these prices? Second, are there any short-run relationships? Third, are these price volatilities interrelated? Fourth, are these relationships changing over time?

These questions are addressed with an analysis of weekly price series for U.S. ethanol, corn, soybean, petroleum-based gasoline (gasoline), and oil. The relationships among these series are investigated using cointegration, vector error corrections (VECM), and multivariate generalized autoregressive conditional heteroskedascity (MGARCH) models. The technical links among prices of corn, soybean, ethanol, gasoline, and oil suggest interactions within these prices. Thus, recognizing 
this feature through a multivariate modeling framework should lead to more relevant empirical models than working with separate univariate models.

The focus of this study is on prices, with the acknowledgment there are other measures of volatility that are associated with consumption, production, or inventories. However, interest is in the overall market with prices as the single statistic for market conditions. As noted by Pindyck [7], price volatility reflects the volatility of current as well as expected future values of production, consumption, and inventory demand.

As discussed by Adrangi et al. [8], for the California oil and diesel fuel markets, microeconomic theory explains the demand for corn as a derived demand, where the price of the final good (ethanol) influences the quantity and thus price of the intermediate good (corn). A secondary effect of expanded corn acreage is an acreage reduction in its major substitute, soybeans, with a corresponding positive soybean price response. Based on this theory, the hypothesized direction of dynamic prices would flow from the price of ethanol to corn and soybean prices. This provides a theoretical justification for the current food versus fuel debate. The increased demand for ethanol fuel translates into an associated higher price which directly impacts the prices of corn and soybeans. However, if the dynamics do not support this ethanol-derived demand hypothesis, an alternative hypothesis of demand by non-ethanol (food) markets may explain prices in the corn and soybean markets.

\section{Data}

The data set includes weekly wholesale price series for U.S. ethanol, corn, soybean, gasoline, and oil, from the last week of March 1989 through the first week of December 2007. Except for U.S. oil prices, all price series are averaged over different locations. Weekly nominal wholesale prices for U.S. ethanol are collected from Ethanol \& Biodiesel News at three U.S. locations: Los Angeles, Houston, and New York City. Petroleum conventional gasoline spot prices for the same three U.S. locations as ethanol prices are collected from the "Weekly Petroleum Status Report" available at the Energy Information Administration website [9]. U.S. FOB weekly West Texas Intermediate oil spot prices are also taken from the Energy Information Administration website [10]. U.S. weekly corn and soybean prices mated with ethanol prices are collected from USDA Agricultural Marketing Service for three U.S. locations: corn prices from Nebraska, Kansas, and Texas and soybean prices from Illinois, Indiana, and Ohio.

Ethanol prices have been particularly sensitive to short-run supply and demand shifts in recent years because of the highly inelastic nature of this market. With the ban and liability issues of the fuel oxygenate additive MTBE (methyl-tertiary-butyl ether), in the short-run, fuel blenders are limited in their ability to switch from ethanol as an oxygenate additive. Also, significant lead time is required in order to bring additional domestic ethanol supplies to market and foreign supply is restricted with a $54 \phi$ per gallon import tariff. This has contributed to the recent boom in ethanol refining and associated increase in ethanol price volatility. To account for this possible structural shift in the relations among these prices, analysis was conducted in terms of the pre-ethanol boom (1989-1999) and ethanol boom (2000-2007) years.

Weekly series for the pre-ethanol and ethanol boom periods for the prices of ethanol, corn, soybeans, gasoline, and oil are tested for the presence of a unit root. A series with a unit root is 
nonstationary with an infinite unconditional variance, and thus, it is not possible to generalize it to other time periods. Following Pindyck [11], the Dickey-Fuller test and augmented Dickey-Fuller test with a time trend, $t$, are performed by estimating the models:

$$
\begin{array}{cr}
\Delta y_{t}=\alpha+\beta t+v y_{t-1}+\varepsilon_{t}, & \text { (Dickey-Fuller test) } \\
\Delta y_{t}=\alpha+\beta t+v y_{t-1}+\sum_{j=1}^{L} \lambda_{j} \Delta y_{t-j}+\varepsilon_{t}, & \text { (Augmented Dickey-Fuller test) }
\end{array}
$$

where $y_{t}$ is the time-series variable, $\Delta$ is the differencing operator, and $\alpha, \beta$, $v$, and $\lambda$ are parameters. As indicated in Tables 1 and 2, all the series generally fail to reject the null hypothesis of a unit root at the $10 \%$ significant level. However, all first differencing of the logarithm of the price series result in

\begin{tabular}{|c|c|c|c|c|c|c|}
\hline \multirow{2}{*}{\multicolumn{2}{|c|}{ Dickey- Fuller ${ }^{a}$}} & \multicolumn{4}{|c|}{ Augmented Dickey-Fuller ${ }^{\text {a }}$} & \multirow[b]{2}{*}{$\mathrm{L}=12$} \\
\hline & & $\mathbf{L}=\mathbf{1}$ & $\mathbf{L}=\mathbf{2}$ & $L=4$ & $\mathbf{L}=\mathbf{8}$ & \\
\hline \multicolumn{7}{|c|}{ Price series $(\mathrm{Pt})$} \\
\hline Ethanol & -2.317 & -2.88 & $-3.366 * * *$ & $-3.209 * * *$ & -3.058 & $-3.409 * * *$ \\
\hline Corn & -1.293 & -1.563 & -1.829 & -2.151 & -2.823 & -2.561 \\
\hline Soybean & -1.743 & -1.726 & -1.816 & -2.03 & -1.895 & -1.831 \\
\hline Gasoline & $-4.029 *$ & $-3.425 * *$ & $-3.726^{* *}$ & $-3.771 * *$ & -2.974 & -3.099 \\
\hline Oil & -2.528 & -2.562 & -2.533 & $-3.209 * * *$ & $-3.890 * *$ & $-3.321 * * *$ \\
\hline \multicolumn{7}{|c|}{ Log price series $(\operatorname{lnPt})$} \\
\hline Ethanol & -2.341 & -2.988 & $-3.436 * *$ & $-3.218 * * *$ & -2.94 & $-3.302 * * *$ \\
\hline Corn & -1.329 & -1.352 & -1.601 & -2.012 & -2.338 & -2.23 \\
\hline Soybean & -1.621 & -1.625 & -1.695 & -1.834 & -1.731 & -1.576 \\
\hline Gasoline & $-3.595 * *$ & $-3.424 * *$ & $-3.589 * *$ & $-3.705 * *$ & -2.785 & -2.941 \\
\hline Oil & -2.302 & -2.482 & -2.387 & -3.058 & $-3.315 * * *$ & -3.002 \\
\hline \multicolumn{7}{|c|}{ Log price change series $(\mathrm{pt}=100 * \ln (\mathrm{Pt} / \mathrm{Pt}-1))$} \\
\hline Ethanol & $-17.542 *$ & $-12.391 *$ & $-10.253 *$ & $-9.720 *$ & $-7.813 *$ & $-5.737 *$ \\
\hline Corn & $-23.348^{*}$ & $-14.827 *$ & $-11.488 *$ & $-9.045^{*}$ & $-6.072 *$ & $-5.800 *$ \\
\hline Soybean & $-22.954 *$ & $-16.322 *$ & $-13.040 *$ & $-11.231 *$ & $-7.780 *$ & $-6.507 *$ \\
\hline Gasoline & $-24.855^{*}$ & $-16.417 *$ & $-13.053 *$ & $-10.663 *$ & $-9.017 *$ & $-6.948^{*}$ \\
\hline Oil & $-22.542 *$ & $-16.786^{*}$ & $-13.040 *$ & $-9.062 *$ & $-6.973 *$ & $-6.204 *$ \\
\hline
\end{tabular}
rejecting the null hypothesis at the $1 \%$ significant level, indicating stationarity.

Table 1. Dickey -Fuller and Augmented Dickey -Fuller Unit Root Summary Statistics for the Pre-Ethanol Boom Years 1989 - 1999.

a $*, * *$, and $* * *$ denote significance at a $1 \%, 5 \%$, and $10 \%$ level, respectively, and $\mathrm{L}$ denotes the lag length.

\section{Cointegration Estimation}

Two or more price series are said to be cointegrated if the prices move together in the long-run. As discussed by Engle and Granger [12], a linear combination of two or more non-stationary series which 
share the same order of integration may be stationary. If such a stationary linear combination exists, the series are said to be cointegrated and long-run equilibrium relationships exist. Although there may be short-run developments that can cause series to deviate, there is a long-run equilibrium relation represented as a linear combination, which ties the individual price series together.

Table 2. Dickey -Fuller and Augmented Dickey -Fuller Unit Root Summary Statistics for the Ethanol Boom Years 2000-2007.

\begin{tabular}{lllllll}
\hline \multirow{2}{*}{ Dickey- Fuller } & \multicolumn{5}{c}{ Augmented Dickey-Fuller $^{\text {a }}$} \\
\cline { 2 - 6 } & $\mathbf{L}=\mathbf{1}$ & $\mathbf{L}=\mathbf{2}$ & $\mathbf{L}=\mathbf{4}$ & $\mathbf{L}=\mathbf{8}$ & $\mathbf{L}=\mathbf{1 2}$ \\
\hline Price series (Pt) & & & & & \\
Ethanol & -1.878 & $-3.290^{* * *}$ & $-4.255^{*}$ & $-3.797^{* *}$ & $-3.180^{* * *}$ & -2.626 \\
Corn & -1.743 & -1.582 & -1.439 & -1.951 & -2.034 & -1.962 \\
Soybean & -0.748 & -1.643 & -1.619 & -1.398 & -2.074 & -1.988 \\
Gasoline & $-3.581^{* *}$ & $-3.327^{* * *}$ & -3.019 & $-3.907 * *$ & $-3.265^{* * *}$ & -2.967 \\
Oil & -1.718 & -2.232 & -2.068 & -2.054 & -1.889 & -1.332
\end{tabular}

Log price series $(\operatorname{lnPt})$

$\begin{array}{lllllll}\text { Ethanol } & -1.663 & -2.957 & -3.567 * * & -3.500^{* *} & -2.743 & -2.513 \\ \text { Corn } & -1.932 & -1.761 & -1.619 & -1.978 & -2.248 & -2.147 \\ \text { Soybean } & -1.193 & -1.929 & -1.973 & -1.833 & -2.319 & -2.113 \\ \text { Gasoline } & -3.143 * * * & -3.228 * * * & -3.273 * * * & -3.564 * * & -3.11 & -2.702 \\ \text { Oil } & -2.219 & -2.67 & -2.488 & -2.502 & -2.399 & -1.957\end{array}$

\begin{tabular}{|c|c|c|c|c|c|c|}
\hline \multicolumn{7}{|c|}{ Log price change series $(\mathrm{pt}=100 * \ln (\mathrm{Pt} / \mathrm{Pt}-1))$} \\
\hline Ethanol & $-11.853 *$ & $-8.620 *$ & $-7.788^{*}$ & $-7.974 *$ & $-6.992 *$ & $-6.654^{*}$ \\
\hline Corn & $-21.761 *$ & $-15.841 *$ & $-12.048 *$ & $-8.227 *$ & $-6.227^{*}$ & $-5.238 *$ \\
\hline Soybean & $-15.361 *$ & $-12.109 *$ & $-10.428 *$ & $-8.871 *$ & $-5.423^{*}$ & $-5.702 *$ \\
\hline Gasoline & $-19.939 *$ & $-14.293 *$ & $-10.935^{*}$ & $-9.341 *$ & $-8.676^{*}$ & $-6.830 *$ \\
\hline Oil & $-17.528 *$ & $-15.120 *$ & $-11.096^{*}$ & $-9.178 *$ & $-7.535^{*}$ & $-6.292 *$ \\
\hline
\end{tabular}

As a test for the presence of cointegration among the price series, the Johansen trace test is performed. Results, presented in Table 3, indicate rejecting the hypotheses of zero or only one cointegration relation for the pre-boom period and no cointegration relations for the ethanol boom period. Based on these trace tests, two cointegration relations are revealed for the pre-ethanol period and one for the ethanol boom period. Searching for the possible long-run relationships among the prices, the likelihood ratio approach is employed. Restricted models with one or more prices not being cointegated are tested against the unrestricted model with all the prices cointegrated. Based on the $\chi^{2}$ between the unrestricted and restricted models, the following cointegration relations are determined: 
Pre-Ethanol Boom:

$$
\begin{gathered}
\ln P_{g}=0.186+0.972 \ln P_{o} \\
(0.044)(0.055) \\
\ln P_{e}=0.114+0.297 \ln P_{c} \\
(0.660)(0.069)
\end{gathered}
$$

Ethanol Boom:

$$
\begin{gathered}
\ln P_{g}=0.082+0.848 \ln P_{o}+0.231 \ln P_{e}, \\
(0.045)(0.057) \quad(0.080)
\end{gathered}
$$

\begin{tabular}{|c|c|c|c|c|}
\hline $\begin{array}{l}\text { Null Hypotheses: } \\
\text { Number of } \\
\text { Cointegration } \\
\text { Relations } \\
\end{array}$ & Eigenvalue & $\begin{array}{c}\text { Trace } \\
\text { Statistic }\end{array}$ & $\begin{array}{c}\text { Critical } \\
\text { Value } \\
0.95 \\
\text { Confidence } \\
\end{array}$ & P-value \\
\hline \multicolumn{5}{|c|}{ Pre-Ethanol Boom Period (1989 - 1999) } \\
\hline 0 & 0.097 & 121.383 & 76.813 & 0.000 \\
\hline 1 & 0.056 & 64.646 & 53.945 & 0.004 \\
\hline 2 & 0.027 & 32.761 & 35.070 & 0.089 \\
\hline 3 & 0.021 & 17.431 & 20.164 & 0.118 \\
\hline 4 & 0.010 & 5.699 & 9.142 & 0.223 \\
\hline \multicolumn{5}{|c|}{ Ethanol Boom Period (2000 - 2007) } \\
\hline 0 & 0.095 & 79.844 & 76.813 & 0.028 \\
\hline 1 & 0.048 & 39.158 & 53.945 & 0.518 \\
\hline 2 & 0.020 & 18.952 & 35.070 & 0.787 \\
\hline 3 & 0.017 & 10.778 & 20.164 & 0.571 \\
\hline 4 & 0.009 & 3.687 & 9.142 & 0.472 \\
\hline
\end{tabular}

where $P_{g}, P_{o}, P_{e}$, and $P_{c}$ are the level prices of gasoline, oil, ethanol, and corn, respectively. Coefficients in parentheses are the standard errors. All the parameter coefficients are significant at the $1 \%$ level with the exception of the intercept terms in the ethanol/corn pre-ethanol relation and the ethanol boom relation which are both significant at the $10 \%$ level.

Table 3. Cointegration Trace Test.

Results from (1) yield two linear relations for the pre-ethanol boom and one relation for the subsequent ethanol boom periods:

Pre-Ethanol Boom Period:

$$
\begin{aligned}
& \left.\begin{array}{c}
\text { Gasoline Prices } \\
\text { Oil Prices }
\end{array}\right] \begin{array}{c}
\text { cointegrated } \\
\text { relation }
\end{array}\left(\begin{array}{c}
\text { long - run equilbrium } \\
\text { relation }
\end{array}\right), \\
& \left.\begin{array}{c}
\text { Ethanol Prices } \\
\text { Corn Prices }
\end{array}\right] \begin{array}{c}
\text { cointegrated } \\
\text { relation }
\end{array}\left(\begin{array}{c}
\text { long - run equilbrium } \\
\text { relation }
\end{array}\right) \text {, }
\end{aligned}
$$


Ethanol Boom Period:

$\left.\begin{array}{c}\text { Gasoline Prices } \\ \text { Oil Prices } \\ \text { Ethanol Prices }\end{array}\right] \begin{gathered}\text { cointegrated } \\ \text { relation }\end{gathered}\left(\begin{array}{c}\text { long - run equilbrium } \\ \text { relation }\end{array}\right)$.

For the pre-ethanol boom period, the analysis indicates gasoline and oil prices exhibit one of the long-run relations with ethanol and corn prices as the other cointegrates. In contrast, results indicate no long-run relation between ethanol and corn prices in the ethanol boom period with only cointegrates among the fuel prices (gasoline, oil, and ethanol). Thus, although there was a long-run relation between ethanol and corn in the pre-ethanol boom period, this relation is not apparent in the subsequent ethanol boom period. In contrast to popular belief, between 2000 and 2007 ethanol and corn do not appear to have any long-run price relationships. However, short-run relations may exist where ethanol prices do influence corn prices and vice versa.

\section{Vector Error Corrections Model (VECM)}

The existence of these cointegrating relationships among the prices indicates there is long-run causality in at least one direction among the prices within the relations, but it does not indicate the direction of price temporal causality. Such causality can be determined with a vector error corrections model (VECM) which specifies the short-run dynamics of each price in a framework that anchors the dynamics to long-run equilibrium relationships (cointegrates). The actual time period of the short-run depends on the nature of the dynamics among the prices. As discussed in Section 4.2, calculating impulse response functions provides an indication of the short-run length.

With the cointegration relations (1), the Granger-type causality test models are augmented with a one period (week) lagged error correction term.

Pre-Ethanol Boom Period:

$$
p_{t}=\Pi_{1} E C T_{1, t-1}+\Pi_{2} E C T_{2, t-1}+\sum_{i=1}^{4} \Phi_{i} p_{t-i}+\varepsilon_{t},
$$

where $p_{t}$ is a vector of percentage change in logarithm prices, $\Pi_{1}, \Pi_{2}$, and $\Phi_{i}$ are vectors of the parameters to be estimated. $E C T_{1, t-1}$ and $E C T_{2, t-1}$ are the lagged error correction terms from (1a) and (1b).

Ethanol Boom Period:

$$
p_{t}=\Pi E C T_{t-1}+\sum_{i=1}^{4} \Phi_{i} p_{t-i}+\varepsilon_{t}
$$

where $E C T_{t-1}$ is the lagged error correction term from (1c).

The Final Prediction Error and Akaike's statistics are computed for determining the lag length in the VECM specifications. These statistics indicate a lag length of four for the pre-ethanol boom period and two for the ethanol boom period. Estimation of the models for alternative lag lengths yielded robust results with nearly identical estimated coefficients. For reporting consistent results, a four-lag specification is selected for both the pre-ethanol and ethanol boom periods.

Employing (2) yields three tests for causality: 1. The short-run causal effects analyzed with a $\chi^{2}-$ statistic of the lagged explanatory variables; 2 . The long-run causal effects, associated with the prices 
that are cointegrated, analyzed using a t-statistic on the coefficient of the lagged error-correction term; and 3. Market shock effects, associated with prices that are not cointegrated, also analyzed using the tstatistic of the lagged error-correction term.

Results from estimating (2) are presented in Appendix Tables A1 and A2 for the pre-ethanol boom and ethanol boom periods, respectively. The associated Granger causality statistics are listed in Tables A3 and A4. Based on these results, causalities among the price series for the pre-ethanol boom and ethanol boom periods are listed in Table 4. In the short-run for both periods, Causalities 1 and 2 indicate that increases in the price of gasoline are driving up ethanol and oil prices while the price of corn influences soybean prices (Causality 6):

Table 4. Granger Causality Test ${ }^{\mathrm{a}}$.

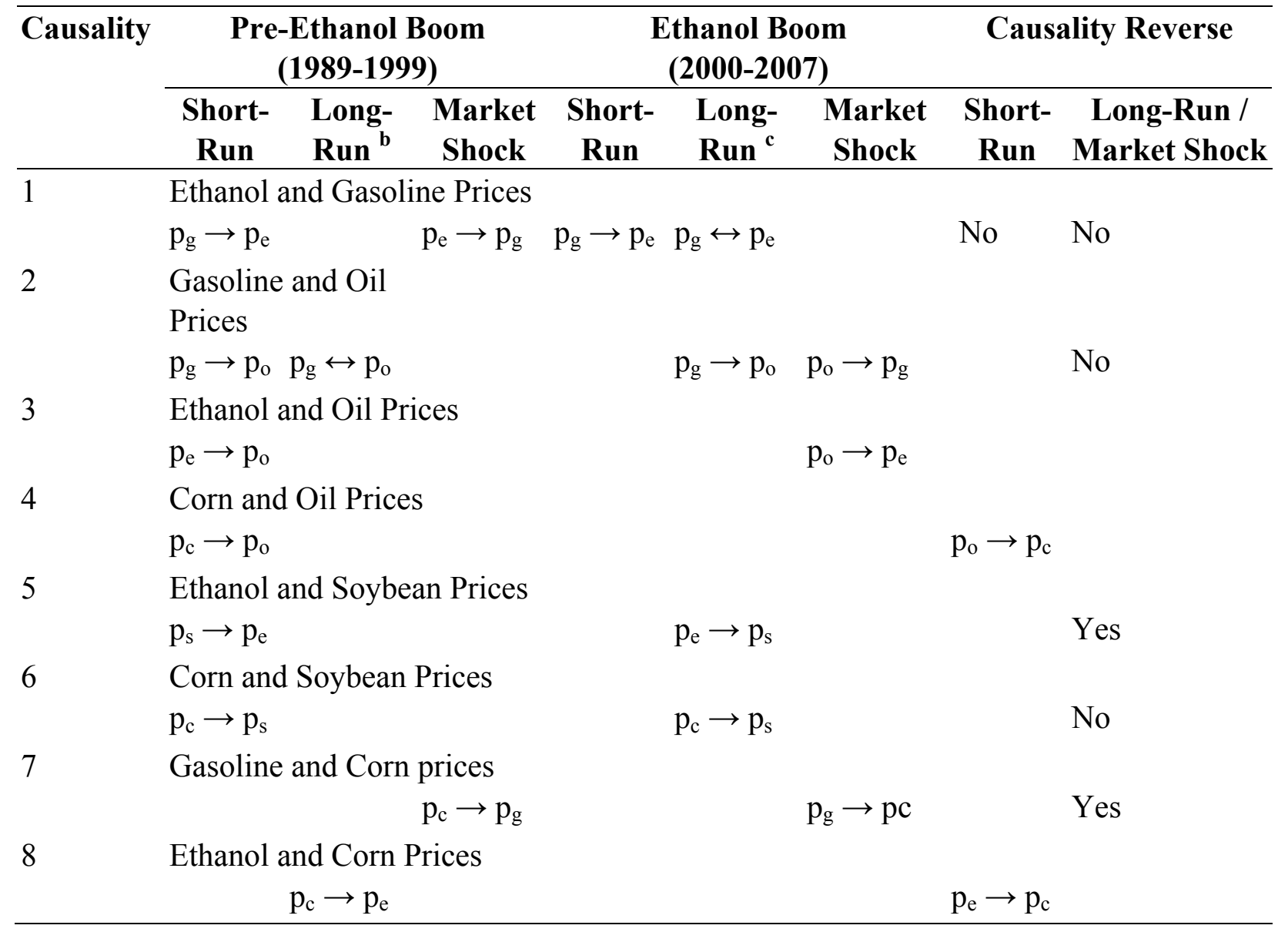

${ }^{\mathrm{a}}$ Long-run and market shock causal effects are associated with cointegrated prices and noncointegrated prices, respectively. The arrow, $\rightarrow$, indicates the direction of Granger causality. Prices of ethanol, corn, soybean, gasoline, and oil, in terms of percentage change in logs, are $p_{e}, p_{c}, p_{s}, p_{g}$, and $p_{0}$, respectively. Exceptions are the long-run and market shock relations which are in terms of log price causing log change in price.

${ }^{\mathrm{b}}$ Two long-run relations (cointegrates): 1. Relationship between gasoline and oil prices and 2 . Relationship between ethanol and corn prices.

${ }^{\mathrm{c}}$ Long-run relation among gasoline, oil, and ethanol prices.

$$
p_{g} \stackrel{\text { Short run }}{\rightarrow}\left\{\begin{array}{l}
p_{e} \\
p_{o}
\end{array},\right. \text { for both the pre-ethanol and ethanol boom periods, }
$$


$p_{c} \stackrel{\text { Short run }}{\longrightarrow} p_{s}$, for both the pre-ethanol and ethanol boom periods,

where $\rightarrow$ indicates the direction of causation. This supports the microeconomic theory hypothesis of a derived demand for ethanol and oil associated with fuel production. The ever-increasing demand for gasoline within the U.S. and the existing tight world oil market underlies this ethanol and oil derived demand. As the demand for vehicle fuels increases, the input demand for ethanol and gasoline increases. In terms of corn prices influencing soybean prices, a positive corn acreage response to an own price enhancement reduces soybean acreage and associated harvest, thus driving up price.

As indicated by the pre-ethanol boom period, Causalities 2, 3, and 4, gasoline, ethanol, and corn prices determine the short-run direction of oil prices:

$\left.\begin{array}{l}p_{g} \\ p_{e} \\ p_{c}\end{array}\right\} \stackrel{\text { Short run }}{\rightarrow} p_{o}$, for the pre-ethanol boom period.

During this period the demand for oil appears to be driven by its use in vehicle fuels and agricultural commodity production. Also, during this pre-boom period, prices of gasoline along with soybean prices influence ethanol prices (Causalities 1 and 5):

$\left.\begin{array}{l}p_{g} \\ p_{s}\end{array}\right\} \stackrel{\text { Short run }}{\longrightarrow} p_{e}$, for the pre-ethanol boom period.

This indicates that gasoline prices not only directly influence oil prices but also indirectly influence them by impacting ethanol prices which influence oil prices. Similarly, with corn prices impacting soybean prices (Causality 6), prices of corn indirectly influence ethanol prices.

The long-run causality, associated with the cointegrates, and the market shock causality, associated with the non-cointegrates, indicate the direction of causation among the cointegrates. Corn prices are influencing the prices of vehicle fuels (ethanol and gasoline) and between the two fuel prices, ethanol prices are influencing gasoline (Causalities 1, 7, and 8):

$$
\begin{aligned}
& p_{c} \stackrel{\text { Long run }}{\rightarrow} p_{e} \text {, and } \\
& \left.\begin{array}{l}
p_{c} \\
p_{e}
\end{array}\right\} \stackrel{\text { Market shock }}{\longrightarrow} p_{g} \text {, for the pre-ethanol boom period. }
\end{aligned}
$$

The relatively small market for ethanol during this period accounts for corn prices influencing ethanol prices, and the general economic conditions influencing the corn and ethanol markets possibly accounts for their market influence on gasoline prices.

Considering the ethanol boom period, the relationship among the agricultural commodity prices (corn and soybeans) and fuel prices (ethanol, gasoline, and oil) result in a causality reversal (Causalities 5, 7, and 8). After the year 1999, instead of gasoline, ethanol, and corn driving the demand for oil (Causalities 2, 3, and 4), a reversal occurs with oil prices now influencing gasoline, ethanol, and corn prices. Fuel prices (ethanol, oil, and gasoline) are now impacting corn prices: 


$$
\left.\begin{array}{l}
p_{o} \\
p_{g} \\
p_{e}
\end{array}\right\} \stackrel{\text { Market shock }}{\longrightarrow} p_{c} \text {, for the ethanol boom period. }
$$

\subsection{Variance-Decomposition}

The significance of the reversal with fuel prices now directly influencing agricultural commodity prices has sparked the current food versus fuel security issue. Providing evidence on this issue, variance-decomposition and impulse response curves indicate that ethanol prices cause only a small short-run impact on soybean prices and any ethanol market shock on corn prices is not persistent. There is no long-run relation (cointegrate) between ethanol and corn prices.

Variance-decomposition provides information on the relative magnitude of the causation influence of one price on another. Performing variance-decomposition analysis measures the effect of shocks in each price on the current and future values of a given price. Specifically, decomposition reflects the percentage of the variance associated with each price in the VECM caused by shocks to the other prices.

The variance-decomposition statistics after five weeks are listed in Table 5. For the pre-ethanol boom period, the variability of the gasoline price contributes $41.4 \%$ and $17.4 \%$ of the variance of the oil and ethanol prices, respectively, and the corn price variability effect on soybeans is $38 \%$. In contrast, short-run causality for the ethanol and corn prices on oil prices are only around $1 \%$ and $2 \%$. This variance-decomposition analysis further supports the significant positive influence of gasoline prices on oil and ethanol prices, and corn prices on soybean prices with a general minor or lack of any causality relations among the other price series.

Table 5. Variance-Decompositions after Five Periods (Weeks).

\begin{tabular}{|c|c|c|c|c|c|}
\hline \multirow{2}{*}{$\begin{array}{l}\text { Forecast Error for } \\
\text { Log Prices of }\end{array}$} & \multicolumn{5}{|c|}{ Contributions of the Shocks in Log Prices of } \\
\hline & Gasoline & Oil & Ethanol & Corn & Soybeans \\
\hline \multicolumn{6}{|c|}{ Pre-Ethanol Boom Period (1989-1999) } \\
\hline Gasoline & 0.952 & 0.027 & 0.010 & 0.007 & 0.004 \\
\hline Oil & 0.414 & 0.554 & 0.009 & 0.022 & 0.001 \\
\hline Ethanol & 0.174 & 0.032 & 0.791 & 0.002 & 0.001 \\
\hline Corn & 0.004 & 0.007 & 0.004 & 0.973 & 0.012 \\
\hline Soybean & 0.010 & 0.000 & 0.001 & 0.380 & 0.609 \\
\hline \multicolumn{6}{|c|}{ Ethanol Boom Period (2000-2007) } \\
\hline Gasoline & 0.98 & 0.01 & 0.003 & 0.003 & 0.004 \\
\hline Oil & 0.541 & 0.444 & 0.005 & 0.003 & 0.007 \\
\hline Ethanol & 0.173 & 0.001 & 0.818 & 0.006 & 0.002 \\
\hline Corn & 0.006 & 0.003 & 0.018 & 0.968 & 0.005 \\
\hline Soybean & 0.004 & 0.010 & 0.002 & 0.261 & 0.723 \\
\hline
\end{tabular}


This significant influence of gasoline prices on oil and ethanol prices as well as corn prices on soybean prices carries directly over to ethanol boom period with $54.1 \%, 17.3 \%$, and $26.1 \%$ contribution, respectively. Although, for the ethanol boom period, ethanol prices are influencing soybean prices, their causation is small as only $0.2 \%$ of the price variation in soybeans is explained by ethanol price variations. At least in the short-run, ethanol prices are not exerting any significant effect on corn and soybean prices. In combination with the lack of any long-run relations between ethanol prices and agricultural commodity (corn and soybean) prices, the tradeoff between food and fuel (food versus fuel security issue) is not revealed by the empirical results. There appears to be a disconnection between food and fuel. The results do not support the hypothesis that much of the run up in agricultural commodity prices is due to the swelling demand for ethanol fuel. Instead, the alternative hypothesis of demand by non-ethanol (food) markets may explain the inflation.

\subsection{Impulse Response}

One possible reason for this food versus fuel disconnection is the lack of any persistence in corn prices given a shock to its price. Such persistence of a deviation in price from its trend is revealed in impulse response curves. The response functions measure the effect of a one standard-deviation shock of a given variable on current and future values of the variables. As illustrated in Figure 1, impulse response curves for fuel price short-run effects on corn prices indicate corn prices have little, if any, response to fuel price shocks. Within a short-run ten-week period, corn prices converge toward their long-run equilibrium from an ethanol price shock and within 15 weeks for shocks in oil and petroleum gasoline prices. This lack of corn-price persistence to an ethanol price shock indicates a rapid market response mitigating ethanol-price effects on corn prices.

Figure 1. Impluse Responses for thanol, Gasoline, and Oil Price Shocks on the Corn Prices for the Ethanol Boom Period 2000-2007.

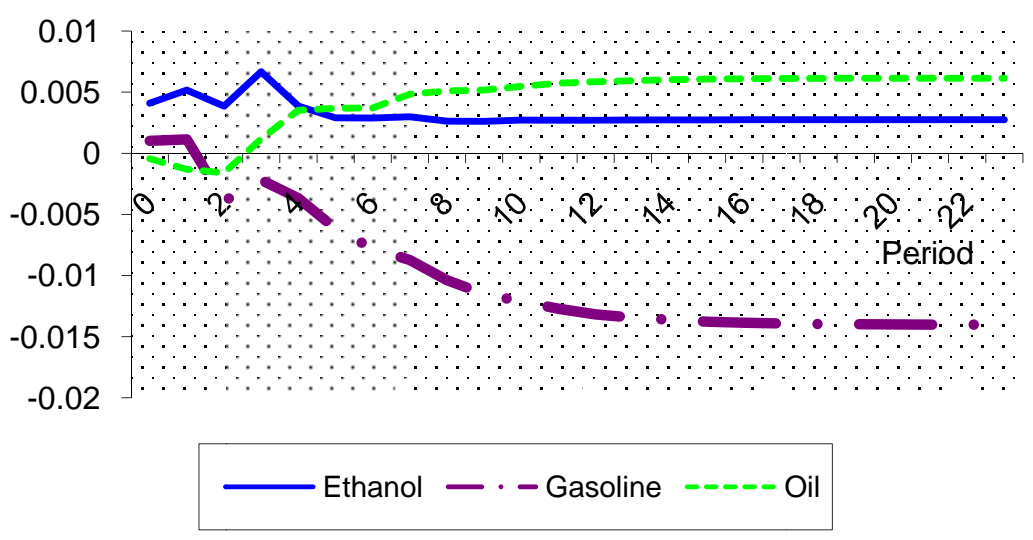

\section{MGARCH}

Similar to the VECM, the MGARCH results in modeling price volatility yield a link between oil and gasoline price volatilities as well as a link between corn and soybean price volatilities over both the pre-ethanol and ethanol boom periods (Table 6). Specifically, a BEKK specification of MGARCH 
$(1,1)$ is employed which allows for dynamic correlations among the prices [13]. Denoting the conditional covariance matrix as $\mathrm{H}_{\mathrm{t}}$, an $\operatorname{MGARCH}(1,1)$ can be written as:

$$
\mathrm{H}_{\mathrm{t}}=\mathrm{C}^{\prime} \mathrm{C}+\mathrm{A}^{\prime} \varepsilon_{\mathrm{t}-1} \varepsilon_{\mathrm{t}-1}^{\prime} \mathrm{A}+\mathrm{G}^{\prime} \mathrm{H}_{\mathrm{t}-1} \mathrm{G},
$$

where $\mathrm{C}, \mathrm{A}$, and $\mathrm{G}$ are $5 \times 5$ square matrices of parameters with $\mathrm{C}$ a lower triangular matrix and $\varepsilon_{\mathrm{t}-1}$ is the error term (deviations from the mean). The A matrix measures the extent that conditional variance and covariances are correlated with past squared errors and captures the effects of shocks or events on volatilities (conditional variances). Matrix $G$ depicts the extent that current levels of conditional variances and covariances are related to the past conditional variances and covariances. This BEKK model yields dynamic variances (conditional variances which are the diagonal elements of $\mathrm{H}_{t}$ ) as measures of volatilities which are functions of past and current disturbances. Results of applying the MGARCH model to the pre-ethanol and ethanol boom periods are provided in Appendix Tables A5 and A6.

In contrast to popular beliefs, no links with ethanol volatilities influencing corn and soybean price volatilities are established. Instead, during the ethanol boom period, a shock in soybean prices (ARCH effects) and soybean price volatility (GARCH effects) both impacting ethanol price volatility. A shock in soybean prices also impacts gasoline volatility, and corn price volatility impacts oil price volatility. These impacts of agricultural commodity price volatility on energy price volatility may indicate some other underlying effect not considered in the models. Specifically, the general increase in world living standards may be impacting the price volatilities of both agricultural and energy commodity prices. Particularly in Asia, enhanced incomes are leading to increased demand for meat and dairy products, along with subsequent demand for their food inputs (corn and soybeans) and energy inputs (oil, gasoline, and ethanol).

Table 6. Impacts of the MGARCH Model ${ }^{\mathrm{a}}$.

\begin{tabular}{cccccc}
\hline \multicolumn{2}{c}{$\begin{array}{c}\text { Pre-Ethanol Boom } \\
\text { (1989-1999) }\end{array}$} & \multicolumn{2}{c}{$\begin{array}{c}\text { Ethanol Boom } \\
(\mathbf{2 0 0 0 - 2 0 0 7 )}\end{array}$} \\
\hline ARCH Effects & & & & & \\
Shock & & Response & Shock & & Response \\
$\varepsilon_{\mathrm{ot}}$ & $\rightarrow$ & $\mathrm{h}_{\mathrm{gt}+1}$ & $\varepsilon_{\mathrm{ot}}$ & $\rightarrow$ & $\mathrm{h}_{\mathrm{gt}+1}$ \\
& & & $\varepsilon_{\mathrm{gt}}$ & $\rightarrow$ & $\mathrm{h}_{\mathrm{ot}+1}$ \\
& & & $\varepsilon_{\mathrm{st}}$ & $\rightarrow$ & $\mathrm{h}_{\mathrm{et}+1}, \mathrm{~h}_{\mathrm{gt}+1}$ \\
& & & $\varepsilon_{\mathrm{ct}}$ & $\rightarrow$ & $\mathrm{h}_{\mathrm{st}+1}$ \\
GARCH Effects & & & & & \\
Volatility & & Influence & Volatility & & Influence \\
$\mathrm{h}_{\mathrm{ot}}$ & $\rightarrow$ & $\mathrm{h}_{\mathrm{gt}+1}$ & $\mathrm{~h}_{\mathrm{ot}}$ & $\rightarrow$ & $\mathrm{h}_{\mathrm{gt}+1}$ \\
$\mathrm{~h}_{\mathrm{gt}}$ & $\rightarrow$ & $\mathrm{h}_{\mathrm{ot}+1}$ & $\mathrm{~h}_{\mathrm{gt}}$ & $\rightarrow$ & $\mathrm{h}_{\mathrm{ot}+1}$ \\
$\mathrm{~h}_{\mathrm{st}}$ & $\rightarrow$ & $\mathrm{h}_{\mathrm{ct}+1}$ & $\mathrm{~h}_{\mathrm{st}}$ & $\rightarrow$ & $\mathrm{h}_{\mathrm{ct}+1}, \mathrm{~h}_{\mathrm{et}+1}$ \\
$\mathrm{~h}_{\mathrm{ct}}$ & $\rightarrow$ & $\mathrm{h}_{\mathrm{st}+1}$ & $\mathrm{~h}_{\mathrm{ct}}$ & $\rightarrow$ & $\mathrm{h}_{\mathrm{st}+1}, \mathrm{~h}_{\mathrm{ot}+1}$ \\
\hline
\end{tabular}

${ }^{a}$ Shocks from a price are $\varepsilon_{\mathrm{o}}, \varepsilon_{\mathrm{g}}, \varepsilon_{\mathrm{s}}$, and $\varepsilon_{\mathrm{c}}$ for oil, gasoline, soybean, and corn price shocks, respectively. Price volatilities $h_{g}, h_{o}, h_{e}, h_{s}$, and $h_{c}$ are associated with gasoline, oil, ethanol, soybeans, and corn, respectively. 
The VECM and MGARCH results indicate that popular beliefs may be confusing the link of shocks in the fuel market (oil, gasoline, and ethanol) influencing short-run corn prices, and volatility in the agricultural commodity markets impacting fuel price volatilities as a persistent long-run ethanol influence on agricultural commodity prices. In the ethanol boom period, no long-run relationship is revealed between agricultural commodity prices and fuel prices. Any short-run relations are not persistent, with agricultural prices returning to their historic long-run trend. A positive fuel-price shock may increase agricultural commodity prices, but the lack of commodity price persistence to such a shock results in commodity prices relatively rapidly mean reverting. The flexibility of agricultural acreage and yield enhancement abilities mitigates any price shocks. The price of corn and soybeans reflects this flexibility by integrating the current as well as expected future values of yields, consumption, and inventories.

\section{Conclusions}

Results obtained in this study are consistent with economic theory. In terms of derived demand theory, our results support the notion of ethanol and oil demands as derived demands from vehicle-fuel production. Gasoline prices directly influence the prices of ethanol and oil. However, of greater significance for the fuel versus food security issue, results support the effect of agricultural commodity prices as market signals which restore commodity markets to their equilibriums after a demand or supply event (shock). As the results indicate, such shocks may, in the short-run, increase agricultural commodity prices, but decentralized freely operating markets will mitigate the persistence of these shocks. Results indicate in recent years there are no long-run relations among fuel (ethanol, oil and gasoline) prices and agricultural commodity (corn and soybean) prices. As specifically addressed, the recent upward direction of agricultural commodity prices may have been supported by an ethanol demand shift, but the results indicate that such an upward shift is only transitory. Market forces will restore prices toward their equilibrium levels. One caveat to this implication is the upward direction of agricultural prices may be persistent if in the future a major increase in ethanol production shifts substantial amounts arable land out of food production with associated higher food prices. However, biofuels, such as ethanol, are just one part of solving reliance on fossil fuels. Other alternative energies, including solar, wind, and nuclear, will probably play a much larger role relative to bioenergy.

As the share of ethanol in our vehicle fuel mix increases, concern arises with ethanol's impacts on agricultural commodity prices. The initial analysis on ethanol's effects on corn and soybean prices indicates that, while ethanol does not appear to influence the long-run equilibrium level of corn and soybean prices, fuel prices in general may potentially cause transitory short-run agricultural commodity price inflation. Such inflation may have an effect on U.S. economic growth, but the major impact is on the poor in developing countries. Consideration may then be directed toward shifting U.S. agricultural policy for mitigating such commodity-price inflation with commodity buffers for supplementing supplies in years of insufficient harvests. Such commodity buffers could blunt food price spikes caused not only by possible biofuel shocks but also by shocks associated with weather, conflicts, and terrorism. 


\section{References and Notes}

1. Hargreaves, S. Calming Ethanol-Crazed Corn Prices. CNN Fortune \& Money. January 30, 2007. http://money.cnn.com/2007/01/30/news/economy/corn_ethanol/index.htm (last accessed in April 2009).

2. LeBlanc, M.; Prato, A. Ethanol Production from Grain in the United States: Agricultural Impacts and Economic Feasibility. Can. J. Agri. Econ. 1983, 31, 223-231.

3. Meekhof, R.; Tyner, W.; Holland, F. U.S. Agricultural Policy and Gasohol: A policy Simulation. Am. J. Agri. Econ. 1980, 62, 408-415.

4. Webb, S. The Impact of Increased Alcohol Production on Agriculture: A Simulation Study. Am. J. Agri. Econ. 1981, 63, 532-537.

5. ERS, Agricultural Baseline Projections: U.S. Crops, 2008-2017. Economic Research Service, USDA, Briefing Rooms, February 12, 2008, http://www.ers.usda.gov/briefing/Baseline/crops.htm (last accessed in April 2009).

6. Robinson, S. Biofules Backlash Grows in Fuel versus Food Debate. ICIS, February 11, 2008. http://www.icis.com/Articles/2008/02/11/9097781/biofuels-backlash-grows-in-fuel-versus-fooddebate.html (last accessed in April 2009).

7. Pindyck, R.S. Volatility in Natural Gas and Oil Markets. J. En. Dev. 2004, 30, 1-19.

8. Adrangi, B.; A. Chatrath; K. Raffiee; R.D. Ripple. Alaska North Slope Crude Oil Price and the Behavior of Diesel Prices in California. En. Econ. 2001, 23, 29-42.

9. Energy Information Administration (EIA). Conventional Regular Gasoline Spot prices, 2007, http://tonto.eia.doe.gov/dnav/pet/pet_pri_spt_s1_d.htm (last accessed in April 2009).

10. Energy Information Administration (EIA). Cushing, OK WTI Spot Price FOB Crude Oil Prices, 2007. http://tonto.eia.doe.gov/dnav/pet/pet_pri_wco_k_w.htm (last accessed in April 2009).

11. Pindyck, R.S. The Long-Run Evolution of Energy Prices. En. J. 1999, 20, 1-27.

12. Engle, R.F.; Granger, C.W.J. Cointegration and Error Correction Representation, Estimation and Testing. Econometrics 1987, 55, 251-276.

13. Engle, R.F.; Kroner, K.F. Multivariate Simultaneous Generalized ARCH. Econometric Th. 1995, $11,122-150$.

(C) 2009 by the authors; licensee Molecular Diversity Preservation International, Basel, Switzerland. This article is an open-access article distributed under the terms and conditions of the Creative Commons Attribution license (http://creativecommons.org/licenses/by/3.0/). 
Table A1. Pre-Ethanol Boom, 1989-1999 VECM Results.

\begin{tabular}{ccccc}
\hline$p_{\mathrm{g}, \mathrm{t}}$ & $\mathbf{p}_{\mathbf{0}, \mathrm{t}}$ & $\mathbf{p}_{\mathrm{e}, \mathrm{t}}$ & $\mathbf{p}_{\mathrm{c}, \mathrm{t}}$ & $\mathbf{p}_{\mathrm{s}, \mathrm{t}}$ \\
Gasoline & Oil & Ethanol & Corn & Soybean \\
\hline
\end{tabular}

\begin{tabular}{|c|c|c|c|c|c|}
\hline \multicolumn{6}{|c|}{ Error Correction Term } \\
\hline$\alpha_{1}$ & $-0.082 *(0.030)$ & $0.093 *(0.023)$ & $0.006(0.009)$ & $-0.018(0.016)$ & $-0.001(0.017)$ \\
\hline$\alpha_{2}$ & $-0.106 *(0.029)$ & $-0.035(0.022)$ & $-0.039 *(0.009)$ & $-0.014(0.016)$ & $0.018(0.013)$ \\
\hline
\end{tabular}

Gasoline Lags

$\begin{array}{llllll}\mathrm{p}_{\mathrm{g}, \mathrm{t}-1} & -0.041(0.054) & -0.010(0.040) & 0.010(0.016) & 0.050 * * *(0.028) & 0.009(0.023) \\ \mathrm{p}_{\mathrm{g}, \mathrm{t}-2} & 0.037(0.052) & 0.012(0.041) & 0.030 * * *(0.016) & -0.006(0.030) & 0.023(0.024) \\ \mathrm{p}_{\mathrm{g}, \mathrm{t}-3} & 0.006(0.049) & 0.004(0.037) & 0.027 * * *(0.016) & 0.031(0.027) & 0.040(0.023) \\ \mathrm{p}_{\mathrm{g}, \mathrm{t}-4} & -0.010(0.049) & -0.129 *(0.038) & -0.014(0.015) & -0.033(0.027) & -0.017(0.022)\end{array}$

Oil Lags

$\begin{array}{llllll}\mathrm{p}_{\mathrm{o}, \mathrm{t}-1} & 0.055(0.066) & 0.077(0.050) & 0.013(0.020) & -0.073 * *(0.035) & -0.003(0.027) \\ \mathrm{p}_{\mathrm{o}, \mathrm{t}-2} & 0.025(0.066) & -0.027(0.049) & 0.021(0.020) & -0.028(0.035) & -0.001(0.333) \\ \mathrm{p}_{\mathrm{o}, \mathrm{t}-3} & 0.069(0.064) & 0.018(0.049) & 0.006(0.018) & -0.053(0.034) & -0.007(0.030) \\ \mathrm{p}_{\mathrm{o}, \mathrm{t}-4} & 0.048(0.063) & \left.0.221^{*} 0.048\right) & 0.017(0.019) & 0.015(0.035) & 0.006(0.028)\end{array}$

Ethanol Lags

$\begin{array}{llllll}\mathrm{p}_{\mathrm{e}, \mathrm{t}-1} & -0.116(0.144) & -0.155(0.109) & 0.229 *(0.044) & -0.085(0.076) & -0.086(0.063) \\ \mathrm{p}_{\mathrm{e}, \mathrm{t}-2} & 0.168(0.147) & 0.025(0.112) & 0.075^{* * *(0.045)} & 0.174 *(0.078) & 0.071(0.065) \\ \mathrm{p}_{\mathrm{e}, \mathrm{t}-3} & 0.019(0.147) & 0.150(0.110) & 0.114 * *(0.044) & 0.026(0.078) & -0.010(0.066) \\ \mathrm{p}_{\mathrm{e}, \mathrm{t}-4} & -0.156(0.139) & -0.306(0.105) & -0.115(0.042) & -0.007(0.074) & -0.011(0.064)\end{array}$

\section{Corn Lags}

$\begin{array}{llllll}\mathrm{p}_{\mathrm{c}, \mathrm{t}-1} & -0.157 * * *(0.084) & -0.131 * *(0.064) & -0.026(0.026) & -0.005(0.045) & 0.285^{*}(0.037) \\ \mathrm{p}_{\mathrm{c}, \mathrm{t}-2} & 0.027(0.091) & -0.152^{* *}(0.068) & -0.024(0.027) & 0.120^{* *}(0.048) & 0.115^{*}(0.039) \\ \mathrm{p}_{\mathrm{c}, \mathrm{t}-3} & 0.044(0.091) & -0.028(0.068) & 0.008(0.028) & 0.101 * *(0.048) & 0.065(0.040) \\ \mathrm{p}_{\mathrm{c}, \mathrm{t}-4} & -0.122(0.090) & -0.082(0.068) & -0.032(0.027) & 0.129 *(0.048) & 0.050(0.040)\end{array}$

Soybean Lags

\begin{tabular}{llllll}
$\mathrm{p}_{\mathrm{s}, \mathrm{t}-1}$ & $-0.039(0.101)$ & $0.070(0.076)$ & $-0.027(0.031)$ & $-0.052(0.053)$ & $-0.112 * *(0.044)$ \\
$\mathrm{p}_{\mathrm{s}, \mathrm{t}-2}$ & $-0.069(0.101)$ & $-0.030(0.075)$ & $0.057 * * *(0.031)$ & $-0.062(0.054)$ & $-0.049(0.045)$ \\
$\mathrm{p}_{\mathrm{s}, \mathrm{t}-3}$ & $-0.072(0.100)$ & $0.048(0.076)$ & $-0.031(0.030)$ & $-0.055(0.053)$ & $-0.005(0.041)$ \\
$\mathrm{p}_{\mathrm{s}, \mathrm{t}-4}$ & $-0.175 * * *(0.095)$ & $-0.070(0.071)$ & $0.019(0.029)$ & $-0.108 * *(0.050)$ & $0.001(0.040)$ \\
\hline
\end{tabular}

Note: Standard errors are in parentheses and *,**, and $* * *$ denote significance at the $1 \%, 5 \%$ and $10 \%$ level, respectively. Prices of ethanol, corn, soybean, gasoline, and oil, in terms of percentage change, are $p_{e}, p_{c}, p_{s}, p_{g}$, and $p_{o}$, respectively. 
Table A2. Ethanol Boom, 2000-2007 VECM Results.

\begin{tabular}{ccccc}
\hline $\mathbf{p}_{\mathrm{g}, \mathrm{t}}$ & $\mathbf{p}_{\mathrm{o}, \mathrm{t}}$ & $\mathbf{p}_{\mathrm{e}, \mathrm{t}}$ & $\mathbf{p}_{\mathrm{c}, \mathrm{t}}$ & $\mathbf{p}_{\mathrm{s}, \mathrm{t}}$ \\
Gasoline & Oil & Ethanol & Corn & Soybean \\
& & & \\
\hline
\end{tabular}

Error Correction Term

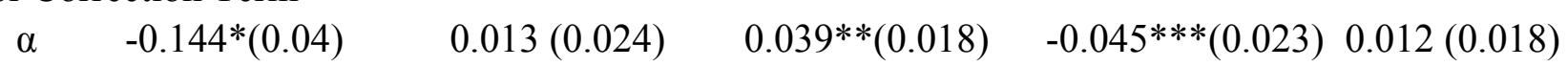

Gasoline Lags

$\begin{array}{llllll}\mathrm{p}_{\mathrm{g}, \mathrm{t}-1} & 0.094(0.065) & 0.109 *(0.039) & 0.079 *(0.030) & 0.052(0.038) & -0.042(0.029) \\ \mathrm{p}_{\mathrm{g}, \mathrm{t}-2} & 0.117 * *(0.065) & 0.092 *(0.040) & -0.025(0.030) & -0.020(0.039) & -0.028(0.029) \\ \mathrm{p}_{\mathrm{g}, \mathrm{t}-3} & 0.105(0.065) & 0.062(0.040) & 0.027(0.029) & 0.035(0.038) & -0.019(0.029) \\ \mathrm{p}_{\mathrm{g}, \mathrm{t}-4} & 0.058(0.063) & -0.004(0.040) & -0.015(0.029) & -0.025(0.038) & -0.060 * *(0.028)\end{array}$

Oil Lags

$\begin{array}{llllll}\mathrm{p}_{\mathrm{o}, \mathrm{t}-1} & 0.045(0.102) & 0.072(0.062) & 0.017(0.047) & -0.075(0.059) & 0.014(0.047) \\ \mathrm{p}_{\mathrm{o}, \mathrm{t}-2} & -0.129(0.101) & -0.206^{*}(0.061) & 0.061(0.046) & -0.056(0.059) & -0.002(0.043) \\ \mathrm{p}_{\mathrm{o}, \mathrm{t}-3} & 0.026(0.099) & 0.035(0.060) & -0.025(0.046) & 0.053(0.058) & 0.061(0.045) \\ \mathrm{p}_{\mathrm{o}, \mathrm{t}-4} & -0.088(0.096) & -0.071(0.058) & 0.101 * *(0.044) & 0.031(0.056) & 0.029(0.042)\end{array}$

Ethanol Lags

$\begin{array}{llllll}\mathrm{p}_{\mathrm{e}, \mathrm{t}-1} & -0.190^{* * *(0.108)} & -0.033(0.066) & 0.356^{*}(0.050) & 0.035(0.063) & -0.126^{*}(0.048) \\ \mathrm{p}_{\mathrm{e}, \mathrm{t}-2} & 0.012(0.118) & -0.108(0.071) & 0.158^{*}(0.054) & -0.054(0.069) & 0.116^{* *}(0.052) \\ \mathrm{p}_{\mathrm{e}, \mathrm{t}-3} & 0.124(0.118) & 0.120^{* * *(0.072)} & 0.042(0.054) & 0.058(0.069) & 0.033(0.052) \\ \mathrm{p}_{\mathrm{e}, \mathrm{t}-4} & -0.011(0.106) & -0.009(0.064) & -0.053(0.049) & -0.145 * *(0.063) & -0.052(0.048)\end{array}$

Corn Lags

$\begin{array}{llllll}\mathrm{p}_{\mathrm{c}, \mathrm{t}-1} & -0.121(0.091) & -0.005(0.058) & 0.013(0.042) & -0.102 * * *(0.053) & 0.075^{* * *}(0.041) \\ \mathrm{p}_{\mathrm{c}, \mathrm{t}-2} & 0.044(0.091) & 0.002(0.048) & 0.077 *(0.042) & -0.083(0.054) & 0.002(0.047) \\ \mathrm{p}_{\mathrm{c}, \mathrm{t}-3} & 0.116(0.091) & 0.023(0.056) & 0.053(0.042) & 0.010(0.053) & 0.153 *(0.040) \\ \mathrm{p}_{\mathrm{c}, \mathrm{t}-4} & -0.099(0.090) & -0.049(0.055) & 0.027(0.041) & 0.089 * * *(0.052) & 0.119 *(0.040)\end{array}$

Soybean Lags

\begin{tabular}{llllll}
$\mathrm{p}_{\mathrm{s}, \mathrm{t}-1}$ & $-0.073(0.118)$ & $-0.078(0.072)$ & $-0.063(0.054)$ & $0.062(0.069)$ & $0.239^{*}(0.053)$ \\
$\mathrm{p}_{\mathrm{s}, \mathrm{t}-2}$ & $-0.118(0.122)$ & $-0.112(0.074)$ & $0.008(0.058)$ & $0.022(0.072)$ & $0.013(0.056)$ \\
$\mathrm{p}_{\mathrm{s}, \mathrm{t}-3}$ & $0.006(0.128)$ & $0.060(0.073)$ & $0.032(0.056)$ & $-0.013(0.070)$ & $-0.074(0.054)$ \\
$\mathrm{p}_{\mathrm{s}, \mathrm{t}-4}$ & $0.181(0.115)$ & $0.103(0.069)$ & $0.058(0.053)$ & $0.082(0.067)$ & -0.070( \\
$\mathrm{p}_{\mathrm{s}, \mathrm{t}-3}$ & $-0.072(0.100)$ & $0.048(0.076)$ & $-0.031(0.030)$ & $-0.055(0.053)$ & $-0.005(0.041)$ \\
$\mathrm{p}_{\mathrm{s}, \mathrm{t}-4}$ & $-0.175 * * *(0.095)$ & $-0.070(0.071)$ & $0.019(0.029)$ & $-0.108 * *(0.050)$ & $0.001(0.040)$ \\
\hline
\end{tabular}

Note: Standard errors are in parentheses and *,**, and *** denote significance at the $1 \%, 5 \%$ and $10 \%$ level, respectively. Prices of ethanol, corn, soybean, gasoline, and oil, in terms of percentage change, are $p_{e}, p_{c}, p_{s}, p_{g}$, and $p_{o}$, respectively. 
Table A3. Granger Causality Tests for the Pre-Ethanol Boom 1989 - 1999.

\begin{tabular}{lccc}
\hline Direction of Causality $^{\mathrm{a}}$ & Short-Run & Long-Run $^{\mathrm{b}}$ & Market Shock $^{\mathrm{c}}$ \\
& $\left(\chi^{2}\right.$ statistics $)$ & $($ t-statistics $)$ & (t-statistics)
\end{tabular}

Ethanol and Corn Prices

$\begin{array}{lll}\mathrm{p}_{\mathrm{e}} \rightarrow \mathrm{p}_{\mathrm{c}} & 6.43 & -0.897 \\ \mathrm{p}_{\mathrm{c}} \rightarrow \mathrm{p}_{\mathrm{e}} & 3.24 & -4.532^{*}\end{array}$

Ethanol and Gasoline Prices
$p_{e} \rightarrow p_{g}$
$\mathrm{p}_{\mathrm{g}} \rightarrow \mathrm{p}_{\mathrm{e}}$
$8.21 * * *$
0.687

Ethanol and Oil Prices
pe $\rightarrow$ po
$12.08 * *$
$p_{o} \rightarrow p_{e}$

0.687

Ethanol and Soybean Prices
$\mathrm{p}_{\mathrm{e}} \rightarrow \mathrm{p}_{\mathrm{s}}$
2.89
$\mathrm{p}_{\mathrm{s}} \rightarrow \mathrm{p}_{\mathrm{e}}$
$9.70 * *$

1.425

Gasoline and Oil Prices
$\mathrm{p}_{\mathrm{g}} \rightarrow \mathrm{p}_{\mathrm{o}}$
$11.70^{* *}$
4.089*
$\mathrm{p}_{\mathrm{o}} \rightarrow \mathrm{p}_{\mathrm{g}}$
2.1
$-2.727^{*}$

Gasoline and Corn Prices
$p_{g} \rightarrow p_{c}$
6.81
$p_{c} \rightarrow p_{g}$

$-1.096$

5.88

$-3.697^{*}$

Gasoline and Soybean Prices
$\mathrm{p}_{\mathrm{g}} \rightarrow \mathrm{p}_{\mathrm{s}}$
$p_{\mathrm{s}} \rightarrow p_{\mathrm{g}}$
3.96

$-0.058$

Oil and Corn Prices

$$
\begin{aligned}
& \mathrm{p}_{\mathrm{o}} \rightarrow \mathrm{p}_{\mathrm{c}} \\
& \mathrm{p}_{\mathrm{c}} \rightarrow \mathrm{p}_{\mathrm{o}}
\end{aligned}
$$

Oil and Soybean Prices

$$
\begin{aligned}
& \mathrm{p}_{\mathrm{o}} \rightarrow \mathrm{p}_{\mathrm{s}} \\
& \mathrm{p}_{\mathrm{s}} \rightarrow \mathrm{p}_{\mathrm{o}}
\end{aligned}
$$$$
-0.058
$$

Corn and Soybean Prices

$$
\begin{aligned}
& \mathrm{p}_{\mathrm{c}} \rightarrow \mathrm{p}_{\mathrm{s}} \\
& \mathrm{p}_{\mathrm{s}} \rightarrow \mathrm{p}_{\mathrm{c}}
\end{aligned}
$$$$
0.018
$$

Note: $* * *$, and $* * *$ indicate significance at the $1 \%, 5 \%$, and $10 \%$ level, respectively.

${ }^{a}$ The arrow, $\rightarrow$, indicates the direction of Granger causality. Prices of ethanol, corn, soybean, gasoline, and oil, in terms of percentage change, are $\mathrm{p}_{\mathrm{e}}, \mathrm{p}_{\mathrm{c}}, \mathrm{p}_{\mathrm{s}}, \mathrm{p}_{\mathrm{g}}$, and $\mathrm{p}_{\mathrm{o}}$, respectively.

${ }^{\mathrm{b}}$ Long-run causal effect is associated with cointegrated prices. Two long-run relations (cointegrates):

1. Relationship between petroleum gasoline and oil prices and 2. Relationship between ethanol and corn prices.

${ }^{\mathrm{c}}$ Market shock causal effects is associated with non-cointegarted prices. 
Table A4. Granger Causality Tests for the Ethanol Boom 2000 - 2007.

\begin{tabular}{cccc}
\hline Direction of Causality $^{\mathrm{a}}$ & Short-Run & Long-Run $^{\mathrm{b}}$ & Market Shock $^{\mathrm{c}}$ \\
& $\left(\chi^{2}\right.$ statistics $)$ & $(\mathrm{t}$-statistics $)$ & (t-statistics)
\end{tabular}

\section{Ethanol and Corn Prices}

$\begin{array}{lc}\mathrm{p}_{\mathrm{e}} \rightarrow \mathrm{p}_{\mathrm{c}} & 6.7 \\ \mathrm{p}_{\mathrm{c}} \rightarrow \mathrm{p}_{\mathrm{e}} & 4.29\end{array}$

$-1.939 * * *$

Ethanol and Gasoline Prices

$\begin{array}{lcc}\mathrm{p}_{\mathrm{e}} \rightarrow \mathrm{p}_{\mathrm{g}} & 3.84 & -3.629^{*} \\ \mathrm{p}_{\mathrm{g}} \rightarrow \mathrm{p}_{\mathrm{e}} & 10.02^{* *} & 2.168^{*} \\ \text { Ethanol and Oil Prices } & & \\ \mathrm{pe} \rightarrow \text { po } & 4.25 & 0.547 \\ \mathrm{p}_{\mathrm{o}} \rightarrow \mathrm{p}_{\mathrm{e}} & 6.21 & 2.168^{* *}\end{array}$

Ethanol and Soybean Prices
$p_{e} \rightarrow p_{s}$
$9.67 * *$
$\mathrm{p}_{\mathrm{s}} \rightarrow \mathrm{p}_{\mathrm{e}}$
3.54

0.664

Gasoline and Oil Prices
$\mathrm{p}_{\mathrm{g}} \rightarrow \mathrm{p}_{\mathrm{o}}$
$11.72 * *$
0.547
$p_{o} \rightarrow p_{g}$
2.98
$-3.629 *$

Gasoline and Corn Prices
$\mathrm{p}_{\mathrm{g}} \rightarrow \mathrm{p}_{\mathrm{c}}$
$\mathrm{p}_{\mathrm{c}} \rightarrow \mathrm{p}_{\mathrm{g}}$
4.86

$-1.939 * * *$

Gasoline and Soybean Prices

$$
\begin{aligned}
& \mathrm{p}_{\mathrm{g}} \rightarrow \mathrm{p}_{\mathrm{s}} \\
& \mathrm{p}_{\mathrm{s}} \rightarrow \mathrm{p}_{\mathrm{g}}
\end{aligned}
$$

Oil and Corn Prices

$$
\begin{aligned}
& \mathrm{p}_{\mathrm{o}} \rightarrow \mathrm{p}_{\mathrm{c}} \\
& \mathrm{p}_{\mathrm{c}} \rightarrow \mathrm{p}_{\mathrm{o}}
\end{aligned}
$$

Oil and Soybean Prices

$$
\begin{aligned}
& \mathrm{p}_{\mathrm{o}} \rightarrow \mathrm{p}_{\mathrm{s}} \\
& \mathrm{p}_{\mathrm{s}} \rightarrow \mathrm{p}_{\mathrm{o}}
\end{aligned}
$$

0.664

Corn and Soybean Prices
$\mathrm{p}_{\mathrm{c}} \rightarrow \mathrm{p}_{\mathrm{s}}$
$21.55^{*}$
$\mathrm{p}_{\mathrm{s}} \rightarrow \mathrm{p}_{\mathrm{c}}$
2.05

Note: $* * *$, and $* * *$ indicate significance at the $1 \%, 5 \%$, and $10 \%$ level, respectively.

${ }^{a}$ The arrow, $\rightarrow$, indicates the direction of Granger causality. Prices of ethanol, corn, soybean, gasoline, and oil, in terms of percentage change, are $p_{e}, p_{c}, p_{s}, p_{g}$, and $p_{o}$, respectively.

b Long-run causal effect is associated with cointegrated prices. Two long-run relations (cointegrates):

1. Relationship between petroleum gasoline and oil prices and 2. Relationship between ethanol and corn prices.

${ }^{\mathrm{c}}$ Market shock causal effects is associated with non-cointegarted prices. 
Table A5. MGARCH(1,1) Results for the Pre-Ethanol Boom 1989-1999.

\begin{tabular}{|c|c|c|c|c|c|}
\hline & $\mathbf{h}_{11, \mathbf{t}+\mathbf{1}}$ (gasoline) & $h_{22, t+1}($ oil) & $\mathbf{h}_{33, \mathrm{t}+\mathbf{1}}($ ethanol) & $h_{44, t+1}($ corn $)$ & $\mathbf{h}_{55, \mathrm{t}+\mathbf{1}}$ (soybean) \\
\hline \multicolumn{6}{|c|}{ Constant } \\
\hline & $0.000(0.000)$ & $0.000 *(0.000)$ & $0.000(0.000)$ & $0.000(0.000)$ & $0.000(0.000)$ \\
\hline \multicolumn{6}{|c|}{$\mathrm{ARCH}$ terms } \\
\hline$\varepsilon_{1, \mathrm{t} 2}$ & $0.059 *(0.018)$ & $0.008(0.005)$ & $0.000(0.000)$ & $0.000(0.000)$ & $0.000(0.000)$ \\
\hline$\varepsilon_{2, \mathrm{t}^{2}}$ & $0.082 *(0.030)$ & $0.001(0.004)$ & $0.000(0.000)$ & $0.000(0.001)$ & $0.000(0.000)$ \\
\hline$\varepsilon_{3, t^{2}}$ & $0.000(0.002)$ & $0.003(0.009)$ & $0.181 *(0.047)$ & $0.000(0.001)$ & $0.000(0.002)$ \\
\hline$\varepsilon_{4, t^{2}}$ & $0.003(0.006)$ & $0.006(0.007)$ & $0.000(0.001)$ & $0.106 *(0.023)$ & $0.005(0.005)$ \\
\hline$\varepsilon_{5, \mathrm{t}^{2}}$ & $0.003(0.007)$ & $0.003(0.005)$ & $0.001(0.001)$ & $0.019(0.017)$ & $0.063 *(0.022)$ \\
\hline$\varepsilon_{1, \mathrm{t}} \varepsilon_{2, \mathrm{t}}$ & $-0.139 *(0.033)$ & $0.006(0.011)$ & $0.000(0.000)$ & $0.000(0.001)$ & $0.000(0.001)$ \\
\hline$\varepsilon_{1, \mathrm{t}} \varepsilon_{3, \mathrm{t}}$ & $-0.003(0.060)$ & $0.010(0.015)$ & $-0.001(0.013)$ & $0.000(0.001)$ & $0.000(0.001)$ \\
\hline$\varepsilon_{1, \mathrm{t}} \varepsilon_{4, \mathrm{t}}$ & $0.025 * *(0.013)$ & $-0.014(0.009)$ & $0.000(0.001)$ & $0.004(0.013)$ & $-0.002(0.003)$ \\
\hline$\varepsilon_{1, \mathrm{t}} \varepsilon_{5, \mathrm{t}}$ & $-0.027(0.035)$ & $0.009(0.009)$ & $0.000(0.001)$ & $-0.002(0.006)$ & $-0.005(0.010)$ \\
\hline$\varepsilon_{2, \mathrm{t}} \varepsilon_{3, \mathrm{t}}$ & $0.004(0.070)$ & $0.004(0.013)$ & $0.028 * * *(0.016)$ & $0.000(0.003)$ & $0.000(0.001)$ \\
\hline$\varepsilon_{2, \mathrm{t}} \varepsilon_{4, \mathrm{t}}$ & $-0.030(0.033)$ & $-0.005(0.010)$ & $0.000(0.001)$ & $0.013(0.023)$ & $0.000(0.004)$ \\
\hline$\varepsilon_{2, \mathrm{t}} \varepsilon_{5, \mathrm{t}}$ & $0.031(0.041)$ & $0.003(0.007)$ & $0.000(0.001)$ & $-0.006(0.010)$ & $-0.001(0.014)$ \\
\hline$\varepsilon_{3, \mathrm{t}} \varepsilon_{4, \mathrm{t}}$ & $-0.001(0.013)$ & $-0.009(0.014)$ & $-0.015(0.017)$ & $0.003(0.043)$ & $-0.002(0.008)$ \\
\hline$\varepsilon_{3, \mathrm{t}} \varepsilon_{5, \mathrm{t}}$ & $0.001(0.013)$ & $0.006(0.010)$ & $0.023(0.023)$ & $-0.001(0.018)$ & $-0.007(0.028)$ \\
\hline$\varepsilon_{4, \mathrm{t}} \varepsilon_{5, \mathrm{t}}$ & $-0.006(0.009)$ & $-0.008(0.009)$ & $-0.001(0.001)$ & $-0.089 * *(0.042)$ & $0.037 * * *(0.019)$ \\
\hline \multicolumn{6}{|c|}{ GARCH terms } \\
\hline $\mathrm{h}_{11, \mathrm{t}}$ & $0.548 *(0.025)$ & $0.066 *(0.008)$ & $0.000(0.000)$ & $0.000(0.000)$ & $0.000(0.000)$ \\
\hline $\mathrm{h}_{22, \mathrm{t}}$ & $0.202 *(0.022)$ & $1.242 *(0.035)$ & $0.000(0.000)$ & $0.000(0.000)$ & $0.001(0.001)$ \\
\hline $\mathrm{h}_{33, \mathrm{t}}$ & $0.001(0.006)$ & $0.008(0.011)$ & $0.722 *(0.058)$ & $0.000(0.000)$ & $0.000(0.000)$ \\
\hline $\mathrm{h}_{44, \mathrm{t}}$ & $0.000(0.002)$ & $0.014(0.012)$ & $0.000(0.000)$ & $0.677 *(0.034)$ & $0.048 *(0.013)$ \\
\hline $\mathrm{h}_{55, \mathrm{t}}$ & $0.001(0.005)$ & $0.021(0.014)$ & $0.000(0.001)$ & $0.105 *(0.025)$ & $0.793 *(0.071)$ \\
\hline $\mathrm{h}_{12, \mathrm{t}}$ & $0.666 *(0.039)$ & $-0.571 *(0.035)$ & $0.000(0.000)$ & $0.000(0.000)$ & $0.000(0.001)$ \\
\hline $\mathrm{h}_{13, \mathrm{t}}$ & $0.047(0.134)$ & $-0.045(0.033)$ & $-0.021(0.016)$ & $0.000(0.001)$ & $0.000(0.000)$ \\
\hline $\mathrm{h}_{14, \mathrm{t}}$ & $0.025(0.094)$ & $-0.061 * *(0.027)$ & $0.000(0.000)$ & $0.015(0.028)$ & $-0.001(0.008)$ \\
\hline $\mathrm{h}_{15, \mathrm{t}}$ & $-0.050(0.116)$ & $0.074 *(0.026)$ & $-0.001(0.001)$ & $0.006(0.011)$ & $0.003(0.033)$ \\
\hline $\mathrm{h}_{23, \mathrm{t}}$ & $0.029(0.082)$ & $0.194(0.142)$ & $0.028(0.020)$ & $0.000(0.000)$ & $0.000(0.002)$ \\
\hline $\mathrm{h}_{24, \mathrm{t}}$ & $0.015(0.057)$ & $0.264 * *(0.116)$ & $0.000(0.001)$ & $-0.005(0.040)$ & $-0.012(0.011)$ \\
\hline $\mathrm{h}_{25, \mathrm{t}}$ & $-0.031(0.070)$ & $-0.322 *(0.111)$ & $0.001(0.001)$ & $-0.002(0.016)$ & $0.050(0.044)$ \\
\hline $\mathrm{h}_{34, \mathrm{t}}$ & $0.001(0.005)$ & $0.021(0.018)$ & $-0.009(0.031)$ & $-0.002(0.086)$ & $-0.002(0.016)$ \\
\hline $\mathrm{h}_{35, \mathrm{t}}$ & $-0.002(0.008)$ & $-0.025(0.020)$ & $0.035(0.052)$ & $-0.001(0.034)$ & $0.009(0.066)$ \\
\hline $\mathrm{h}_{45, \mathrm{t}}$ & $-0.001(0.005)$ & $-0.034(0.019)$ & $0.000(0.001)$ & $0.532 *(0.065)$ & $-0.392 *(0.054)$ \\
\hline
\end{tabular}

Note: Standard errors are in parenthesis and *,**, and $* * *$ denote significance at $1 \%, 5 \%$, and $10 \%$ level, respectively. $h_{11}, h_{22}, h_{33}, h_{44}$, and $h_{55}$ denote volatilities of gasoline, oil, ethanol, corn, and soybean, respectively, and $\varepsilon_{1}, \varepsilon_{2}, \varepsilon_{3}, \varepsilon_{4}$, and $\varepsilon_{5}$ denote shocks in percentage change prices of gasoline, oil, ethanol, corn, and soybean, respectively. 
Table A6. MGARCH(1,1) Results for the Ethanol Boom 2000-2007.

\begin{tabular}{|c|c|c|c|c|c|}
\hline & $\mathbf{h}_{11, t+1}$ (gasoline) & $h_{22, t+1}$ (oil) & $h_{33, t+1}$ (ethanol) & $h_{44, t+1}(\operatorname{corn})$ & $h_{55, t+1}$ (soybean) \\
\hline \multicolumn{6}{|c|}{ Constant } \\
\hline & $0.000(0.000)$ & $0.000(0.000)$ & $0.000(0.000)$ & $0.000(0.000)$ & $0.000(0.000)$ \\
\hline \multicolumn{6}{|c|}{ ARCH terms } \\
\hline$\varepsilon_{1, t} 2$ & $0.076 *(0.027)$ & $0.013 * *(0.006)$ & $0.004(0.004)$ & $0.000(0.001)$ & $0.002(0.002)$ \\
\hline$\varepsilon_{2, t} 2$ & $0.107 * *(0.049)$ & $0.001(0.003)$ & $0.001(0.002)$ & $0.014(0.012)$ & $0.003(0.004)$ \\
\hline$\varepsilon_{3, t} 2$ & $0.009(0.016)$ & $0.003(0.005)$ & $0.221 *(0.062)$ & $0.009(0.012)$ & $0.000(0.002)$ \\
\hline$\varepsilon_{4, \mathrm{t}} 2$ & $0.001(0.003)$ & $0.001(0.002)$ & $0.006(0.006)$ & $0.068 *(0.024)$ & $0.023 * * *(0.012)$ \\
\hline$\varepsilon_{5, \mathrm{t}} 2$ & $0.051 *(0.017)$ & $0.009(0.010)$ & $0.036^{* * *}(0.020)$ & $0.003(0.007)$ & $0.115 *(0.031)$ \\
\hline$\varepsilon_{1, \mathrm{t}} \varepsilon_{2, \mathrm{t}}$ & $-0.18 *(0.052)$ & $-0.008(0.010)$ & $0.004(0.006)$ & $-0.004(0.007)$ & $-0.005(0.004)$ \\
\hline$\varepsilon_{1, \mathrm{t}} \varepsilon_{3, \mathrm{t}}$ & $-0.053(0.046)$ & $-0.012(0.011)$ & $-0.063 * *(0.026)$ & $0.003(0.006)$ & $0.002(0.005)$ \\
\hline$\varepsilon_{1, \mathrm{t}} \varepsilon_{4, \mathrm{t}}$ & $0.014(0.013)$ & $0.007(0.010)$ & $-0.011 * * *(0.006)$ & $-0.009(0.015)$ & $-0.014 * * *(0.008)$ \\
\hline$\varepsilon_{1, t} \varepsilon_{5, \mathrm{t}}$ & $-0.124 * *(0.053)$ & $-0.022 * * *(0.013)$ & $0.025(0.012)$ & $-0.002(0.004)$ & $0.032 * *(0.016)$ \\
\hline$\varepsilon_{2, t} \varepsilon_{3, \mathrm{t}}$ & $0.063(0.055)$ & $0.004(0.008)$ & $0.034(0.043)$ & $-0.022(0.018)$ & $-0.002(0.006)$ \\
\hline$\varepsilon_{2, t} \varepsilon_{4, \mathrm{t}}$ & $-0.017(0.042)$ & $-0.002(0.004)$ & $-0.004(0.007)$ & $0.062 * *(0.029)$ & $0.017(0.012)$ \\
\hline$\varepsilon_{2, t} \varepsilon_{5, \mathrm{t}}$ & $0.147 * *(0.066)$ & 0.007 (0.009) & $0.010(0.017)$ & $0.014(0.016)$ & $-0.038(0.025)$ \\
\hline$\varepsilon_{3, \mathrm{t}} \varepsilon_{4, \mathrm{t}}$ & $-0.005(0.013)$ & $-0.003(0.005)$ & $0.075^{* *}(0.034)$ & $-0.049(0.034)$ & $-0.005(0.016)$ \\
\hline$\varepsilon_{3, t} \varepsilon_{5, \mathrm{t}}$ & $0.043(0.041)$ & $0.010(0.011)$ & $-0.179 *(0.056)$ & $-0.011(0.014)$ & $0.011(0.036)$ \\
\hline$\varepsilon_{4, \mathrm{t}} \varepsilon_{5, \mathrm{t}}$ & $-0.012(0.029)$ & $-0.006(0.008)$ & $-0.030 * * *(0.016)$ & $0.030(0.033)$ & $-0.103 *(0.03)$ \\
\hline \multicolumn{6}{|c|}{ GARCH terms } \\
\hline $\mathrm{h}_{11, \mathrm{t}}$ & $0.347 *(0.029)$ & $0.562 *(0.044)$ & $0.000(0.002)$ & $0.013(0.009)$ & $0.000(0.000)$ \\
\hline $\mathrm{h}_{22, \mathrm{t}}$ & $0.534 *(0.066)$ & $0.382 *(0.040)$ & $0.006(0.012)$ & $0.038(0.032)$ & $0.008(0.013)$ \\
\hline$h_{33, t}$ & $0.000(0.002)$ & $0.005(0.012)$ & $0.535 *(0.087)$ & $0.016(0.013)$ & $0.000(0.000)$ \\
\hline$h_{44, t}$ & $0.001(0.003)$ & $0.014 *(0.005)$ & $0.000(0.001)$ & $0.875 *(0.066)$ & $0.097 *(0.019)$ \\
\hline $\mathrm{h}_{55, \mathrm{t}}$ & $0.095(0.060)$ & $0.001(0.008)$ & $0.083^{* *}(0.032)$ & $0.188 *(0.057)$ & $0.387 *(0.077)$ \\
\hline $\mathrm{h}_{12, \mathrm{t}}$ & $0.861 *(0.065)$ & $-0.927 *(0.06)$ & $-0.003(0.007)$ & $-0.044 * * *(0.023)$ & $-0.001(0.006)$ \\
\hline $\mathrm{h}_{13, \mathrm{t}}$ & $-0.012(0.091)$ & $-0.105(0.130)$ & $0.032(0.056)$ & $-0.028 * * *(0.015)$ & $0.000(0.001)$ \\
\hline$h_{14, t}$ & $0.031(0.070)$ & $0.177 *(0.032)$ & $-0.001(0.002)$ & $-0.21 *(0.072)$ & $0.003(0.021)$ \\
\hline $\mathrm{h}_{15, \mathrm{t}}$ & $0.363 *(0.116)$ & $0.055(0.169)$ & $0.013(0.022)$ & $0.097 *(0.036)$ & $0.006(0.042)$ \\
\hline $\mathrm{h}_{23, \mathrm{t}}$ & $-0.015(0.113)$ & $0.087(0.107)$ & $-0.109(0.118)$ & $0.049 * * *(0.029)$ & $-0.001(0.009)$ \\
\hline $\mathrm{h}_{24, \mathrm{t}}$ & $0.038(0.088)$ & $-0.146^{*}(0.027)$ & $0.003(0.006)$ & $0.363 * *(0.153)$ & $-0.057(0.044)$ \\
\hline $\mathrm{h}_{25, \mathrm{t}}$ & $0.451 *(0.145)$ & $-0.045(0.140)$ & $-0.043(0.047)$ & $-0.169^{* *}(0.075)$ & $-0.114(0.088)$ \\
\hline$h_{34, t}$ & $-0.001(0.004)$ & $-0.017(0.021)$ & $-0.025(0.057)$ & $0.236 * *(0.100)$ & $0.002(0.031)$ \\
\hline $\mathrm{h}_{35, \mathrm{t}}$ & $-0.006(0.048)$ & $-0.005(0.017)$ & $0.422 *(0.088)$ & $-0.110 * *(0.049)$ & $0.004(0.062)$ \\
\hline $\mathrm{h}_{45, \mathrm{t}}$ & $0.016(0.037)$ & $0.009(0.027)$ & $-0.010(0.023)$ & $-0.811 * *(0.127)$ & $0.386^{*}(0.055)$ \\
\hline
\end{tabular}

Note: Standard errors are in parenthesis and $* * *$, and $* * *$ denote significance at $1 \%, 5 \%$, and $10 \%$ level, respectively. $h_{11}, h_{22}, h_{33}, h_{44}$, and $h_{55}$ denote volatilities of gasoline, oil, ethanol, corn, and soybean, respectively, and $\varepsilon_{1}, \varepsilon_{2}, \varepsilon_{3}, \varepsilon_{4}$, and $\varepsilon_{5}$ denote shocks in percentage change prices of gasoline, oil, ethanol, corn, and soybean, respectively. 